\title{
PERBANDINGAN KEMAMPUAN BERPIKIR KREATIF MATEMATIS ANTARA SISWA YANG MENDAPATKAN MODEL MIND MAPPING BERBASIS PENGOPTIMALAN FUNGSI OTAK KANAN DAN MODEL PROBLEM BASED LEARNING
}

\author{
Nurul Hamidah ${ }^{1)}$, Sumarni ${ }^{2)}$, Nuranita Adiastuty ${ }^{3)}$ \\ ${ }^{12) 3)}$ Program Studi Pendidikan Matematika, Universitas Kuningan, Kuningan. \\ ${ }^{1)}$ nurulhamidah233@yahoo.co.id ${ }^{2)}$ marnie.1205@gmail.com ${ }^{3)}$ anitha_dyaz2@yahoo.co.id
}

\begin{abstract}
The purpose of study is to compare the increase in mathematical creative thinking ability between students who learn to get a mind mapping model based on optimizing right brain function and Problem Based Learning models. The research method used was a quasi experiment in the form of the pretest post-test two treatment design. The study population was seventh grade students of SMP Negeri 3 Kuningan with sampling using purposive sampling technique. The research instrument used in the form of the test instrument and non-test.The results showed that: (1) there are differences in mathematical creative thinking ability among students who get mind mapping model based on optimization of right brain function and model of Problem Based Learning; (2) there is a difference of improvement of mathematical creative thinking ability between students who get mind mapping model based on optimization of right brain function and model of Problem Based Learning; (3) The average percentage of student responses shows that almost half of the students showed interest in the mind mapping model based on optimization right brain function and the Problem Based Learning model.
\end{abstract}

Keywords: Mathematical Creative Thinking, Mind Mapping, Problem Based Learning.

\begin{tabular}{|l|}
\hline ABSTRAK \\
Penelitian bertujuan untuk membandingkan peningkatan kemampuan \\
berpikir kreatif matematis antara siswa yang pembelajarannya mendapatkan model mind \\
mapping berbasis pengoptimalan fungsi otak kanan dan model Problem Based \\
Learning.Metode penelitian yang digunakan adalah quasi eksperiment bentuk the \\
pretest post-test two treatment design.Populasi penelitianadalah siswa kelas VII SMP \\
Negeri 3 Kuningan dengan pengambilan sampel menggunakan teknik purposive \\
sampling.Instrumen penelitian yang digunakan berupa instrumen tes dan non tes. Hasil \\
penelitian menunjukkan bahwa: (1) terdapat perbedaan kemampuan berpikir kreatif \\
matematis antara siswa yang mendapatkan model mind mapping berbasis \\
pengoptimalan fungsi otak kanan dan model Problem Based Learning; (2) terdapat \\
perbedaan peningkatan kemampuan berpikir kreatif matematis antara siswa yang \\
mendapatkan model mind mapping berbasis pengoptimalan fungsi otak kanan dan \\
model Problem Based Learning; (3) Presentase rata-rata respon siswa menunjukkan
\end{tabular}


bahwa hampir setengahnya siswa menunjukkan minat terhadap model mind mapping berbasis pengoptimalan fungsi otak kanan dan model Problem Based Learning.

Kata Kunci :Berpikir Kreatif Matematis, Mind Mapping, Problem Based Learning.

\section{PENDAHULUAN}

Salah satu bidang studi yang mendukung perkembangan ilmu pengetahuan dan teknologi adalah matematika.Matematika penting untuk dipelajari karena matematika menjadi tolak ukur atau induk dari ilmu pengetahuan (Darusman, 2014). Berdasarkan peraturan menteri pendidikan dan kebudayaan nomor 54 tahun 2013 tentang Standar Kompetensi Lulusan pendidikan dasar dan menengah, kualifikasi kemampuan yang diharapkan diantaranya memiliki kemampuan pikir dan tindak yang efektif dan kreatif dalam ranah abstrak dan konkret sesuai dengan yang dipelajari disekolah dan sumber lain sejenis.

Krathwohl (2002) menyatakan bahwa taksonomi tujuan kependidikan yang disusun oleh Bloom merupakan suatu kerangka untuk mengklasifikasikan hasil pembelajaran yang diharapkan atau niatkan untuk dicapai oleh siswa.Taksonomi Bloom tersebut kemudian direvisi oleh Anderson dan memberikan dimensi baru antara lain mengingat (remember), memahami (understand), menerapkan (apply), menganalisis (analyze), mengevaluasi (evaluate), dan menciptakan (create). Tujuan kependidikan dengan tingkatan paling sulit adalah menciptakan(create), hal tersebut membutuhkan kemampuan berpikir kreatif untuk mencapainya.

Namun dalam prakteknya,banyak guru di pendidikan dasar dan menengah masih kurang memperhatikan kemampuan berpikir kreatif siswanya. Pemikiran yang dilakukan dalam pendidikan matematika di sekolah hanya menekankan pada keterampilan analisis, mengajarkan siswa memahami klaim-klaim, mengikuti/menciptakan argumen logis, menggambarkan jawaban, mengeliminasi jalur yang tak benar dan fokus pada jalur yang benar. Selanjutnya Harris berpendapat bahwa jenis berpikir yang lain yaitu berpikir kreatif, kurang begitu diperhatikan. Padahal kemampuan berpikir kreatif sangat penting karena bersifat fokus pada penggalian ide-ide, memunculkan kemungkinan-kemungkinan dan mencari banyak jawaban benar dari pada satu jawaban.Hal tersebut mengakibatkankemampuan berpikir kreatif matematis siswa masih rendah.

Tingkat kreativitas anak-anak Indonesia dibandingkan negara-negara yang lain berada pada peringkat yang rendah. Hal ini sesuai dengan yang dipaparkan oleh (Jellen \& Urban, 1989) bahwa tingkat kreativitas anak-anak Indonesia adalah yang terendah diantara anak-anak seusianya dari 8 negara lainnya. Penyebab rendahnya kreativitas anak-anak Indonesia diantaranya adalah lingkungan yang kurang menunjang 
untuk mengekspresikan kreativitasnya dan pembelajaran di sekolah yang belum optimal. Menurut Wahyudin (2008) siswa seringkali hanya mencontoh apa yang dikerjakan guru tanpa mencari alternatif lain. Hal ini terjadi karena siswa kurang memiliki kemampuan keluwesan yang merupakan komponen utama kemampuan berpikir kreatif.Hal ini menunjukkan bahwa tingkat kreativitas siswa SMP masih kurang.

Menurut Haylock (Fardah, 2012) berpikir kreatif dapat dibagi menjadi dua pendekatan utama, proses dan produk. Berpikir kreatif yang dipandang dari segi proses merupakan respon siswa dalam menyelesaikan masalah. Dipandang dari segiproduk atau hasil, Treffinger dkk (Fardah, 2012) menguraikan bahwa berpikir kreatif menekankan pada aspek kelancaran (fluency), keluwesan (flexibility), keaslian (originality), dan keterincian (elaboration).

Alternatif model pembelajaran yang diduga dapat meningkatkan kemampuan berpikir kreatif siswa adalah model mind mapping berbasis pengoptimalan fungsi otak kanan dan model Problem Based Learning.

Model Mind mapping adalah model pembelajaran yang mempelajari konsep atau teknik mengingat sesuatu dengan bantuan mind map sehingga kedua otak manusia dapat digunakan secara maksimal (Lestari dan Yudhanegara, 2015:76).Praktik pembelajaran di sekolah umumnya masih berorientasi pada otak kiri dan kurang memberi kesempatan pada berkembanganya fungsi dari otak kanan.Perlu adanya keseimbangan kinerja otak kiri dan otak kanan agarpembelajaran matematika dapat menjadi lebih maksimal.Oleh karena itu, diperlukan adanya pembelajaran dengan model mind mapping berbasis pengoptimalan fungsi otak kanan.Sehingga, pembelajaran matematika di sekolah tidak hanya mengedepankan berkembangnya fungsi otak kiri, tetapi juga mengoptimalkan kinerja otak kanan.

Alternatif model pembelajaran kedua adalah model Problem Based Learning. Bilgin et al. (Khoiri dkk., 2013:115) mengungkapkan bahwa "Dalam Problem Based Learning, masalah yang diajukan oleh guru adalah permasalahan dunia nyata dan menarik, sehingga siswa dilatih untuk memecahkan masalah yang membutuhkan pemikiran kreatif."'Model Problem Based Learning memberikan tantangan kepada siswa, bekerja bersama dalam suatu kelompok untuk menyelesaikan permasalahan.

Berdasarkan pemikiran di atas, maka penulis tertarik untuk mengadakan penelitian dengan judul "Perbandingan Peningkatan Kemampuan Berpikir Kreatif Matematis Antara Siswa yang Mendapatkan Model Mind Mapping Berbasis Pengoptimalan Fungsi Otak Kanan dan Model Problem Based Learning."

Penelitian ini bertujuan untuk mengkaji: (1) kemampuan berpikir 
kreatif matematisantara siswa yang mendapatkan model mind mapping berbasis pengoptimalan fungsi otak kanan dan model Problem Based Learning; (2) peningkatan kemampuan berpikir kreatif matematis antara siswa yang mendapatkan model mind mapping berbasis pengoptimalan fungsi otak kanan dan model Problem Based Learning; dan (3)Mengkajirespon siswa terhadap penggunaan model mind mapping berbasis pengoptimalan fungsi otak kanan dan model Problem Based Learning.

Adapun manfaat penelitian ini secara teoritis ialah menjadi sumber informasi mengenai kemampuan berpikir kreatif matematis dengan model mind mappingdan modelProblem Based Learning pada siswa SMP.Manfaat praktis dari penelitian yaitu: (1) sebagai dasar pemikiran untuk meningkatkan kualitas pembelajaran di sekolah dengan menggunakan model pembelajaran yang tepat; memberdayakan guru matematika dalam menggunakan model pembelajaran mind maping dan modelProblem Based Learning; dan (3) meningkatkan kemampuan berpikir kreatif matematis siswa dalam pembelajaran matematika.

\section{LANDASAN TEORI}

\section{Model Mind Mapping Berbasis Pengoptimalan Fungsi Otak Kanan}

Lestari dan Yudhanegara (2015:76) mengungkapkan bahwa model mind mapping (peta pikiran) adalah model pembelajaran yang mempelajari konsep atau teknik mengingat dengan bantuan mind map sehingga kedua otak manusia dapat digunakan secara maksimal.Model mind mapping berbasis pengoptimalan fungsi otak kanan adalah model yang mempelajari konsep/teknik menyimpan informasi dengan membuat catatan peta pikiranyang mengoptimalkan kemampuan otak kanan melalui aktivitas yang merangsang otak kanan.

Langkah-langkah pembelajaran dengan model mindmapping berbasis pengoptimalan fungsi otak kanan sebagai berikut.

1. Guru menyampaikankompetensi yang ingin dicapai.

2. Gurumengemukakan permasalahan yangakan ditanggapi oleh peserta didik dansebaiknya permasalahan yang mempunyaialternatif jawaban

3. Siswa dibagi ke dalam beberapa kelompokdan berdiskusi mempelajari permasalahandengan bimbingan guru

4. Tiap kelompok mencatat poin-poin penting materi yang disampaikan

5. Tiap kelompok menyajikan kembali materi dalam bentuk mind map berupa bagan atau diagram

6. Perwakilan beberapa kelompok mempresentasikan mind map

7. Siswa dibimbing guru membuat kesimpulan dari pembelajaran

8. Siswa melakukan relaksasi dengan diiringi musik instrumental serta permainan

9. Guru memberikan soal untuk dikerjakan secara individu

Model Problem Based Learning 
Model Problem Based Learning adalah model pembelajaran yang berpusat pada masalah sang sering dijumpai dalam kehidupan seharihari.Sani (2015:140) berpendapat bahwa Problem Based Learning merupakan model pembelajaran yang penyampaiannya dilakukan dengan cara menyampaikan suatu permasalahan, mengajukan pertanyaan-pertanyaan, memfasilitasi penyelidikan dan membuka dialog.

\begin{tabular}{crr}
\multicolumn{2}{c}{ Menurut } & Trianto \\
sintaks model & Problem & Based
\end{tabular}

Learningterdiri dari lima langkah utama yaitu sebagai berikut.

1. Mengorientasikan siswa pada masalah

2. Mengorganisasikan siswa untuk belajar

3. Memandu menyelidiki secara mandiri atau kelompok

4. Mengembangkan dan menyajikan hasil kerja

5. Menganalisis dan mengevaluasi hasil pemecahan masalah

\section{Kemampuan Berpikir Kreatif Matematis}

Munandar (Moma, 2015:28) mendefinisikan bahwa berpikir kreatif ialah memberikan macam-macam kemungkinan jawaban berdasarkan informasi yang diberikan penekanan pada keragaman jumlah dan kesesuaian."

Aspek kemampuan berpikir kreatif matematis menurut Torrance (Lestari \& Yudhanegara, 2015:89) yaitu:
1. Kelancaran (fluency)yaitu kemampuan mempunyai banyak gagasan/jawaban dalam berbagai kategori.

2. Kerincian (elaboration)yaitu kemampuan mengembangkanide/gagasan untuk menyelesaikan masalah secara rinci.

3. Keluwesan (flexibility) yaitu kemampuan mempunyai ide/gagasan yang beragam.

4. Keaslian (originality)yaitu kemampuan mempunyai ide/gagasan baru untuk menyelesaikan persoalan.

\section{METODE PENELITIAN}

\section{Jenis Penelitian}

Penelitian ini menggunakan kuasi eksperimen bentuk the pretest post-test two treatment design.Desain penelitianmenurutCohen, dkk.(Erasanti, 2016:31) sebagai berikut.

Eksperimen 1: $Q_{-\ldots} X_{1--} \Omega$.

Eksperimen 2: $O \quad X_{2} \quad O$

Keterangan:

$O$ : Pretes (sebelum diberi perlakuan)

Postes (sesudah diberi perlakuan)

$X_{1}$ : Perlakuan model mind mapping berbasis pengoptimalan otak kanan

$X_{2}$ : Perlakuan model Problem Based Learning

:Pengambilan sampel tidak dilakukan secara acak. 


\section{Waktu dan Tempat Penelitian}

Penelitian dilakukan di salah satu SMP Negeri di Kuningan pada tanggal 2 - 30 April 2018 pada semester genap tahun ajaran 2017/2018.

\section{Subjek Penelitian}

Subjek dalam penelitian adalah siswa kelas VII SMP.Pengambilan sampel menggunakan teknik purposive sampling.Kelas VII F sebagai kelas eksperimen 1 mendapatkan perlakuan pembelajaran dengan menggunakan model Mind mapping berbasis pengoptimalan fungsi otak kanan. Sedangkan kelas VII H sebagai kelas eksperimen 2 mendapatkan perlakuan dengan model Problem Based Learning.

\section{Prosedur}

Secara garis besar, penelitian yang dilakukan melalui empat tahap yaitu: persiapan, pelaksanaan, analisis data dan penarikan kesimpulan.Tahap persiapan meliputi pengajuan judul, pembuatan proposal, menyusun instrumen, perizinan dan uji coba instrumen.Tahap pelaksanaan meliputi pretes, pelaksanaan pembelajaran di kedua kelas eksperimen dan postes.Tahap analisis data meliputi analisis data kuantitatif yaitu pretes dan postes dan analisis data kualitatif yaitu angket.Tahap penarikan kesimpulan meliputi penarikan kesimpulan dan penyusunan laporan.

Teknik Pengumpulan Data dan Teknik Analisis Data
Teknik pengumpulan data dalam penelitian ini dilakukan melalui teknik tes dan teknik non tes.

1. Teknik tes dianalisis secara kuantitatif

a. Data pretes diperoleh melalui tes yang dilaksanakan sebelum perlakuan diberikan.

b. Data postesdiperoleh melalui tes yang dilaksanakan setelah perlakuan diberikan pada akhir penelitian

c. Data N-Gaingain ternormalisasi merupakan data yang diperoleh dengan membandingkan selisih skor postes dan pretes dengan selisih SMI (Skor Maksimum Ideal) dan pretes.

2. Teknik non tes dianalisis secara kualitatif melalui angket.

\section{HASIL PENELITIAN DAN PEMBAHASAN}

Hasil

Untuk mengetahui kemampuan awal berpikir kreatif matematis siswa, data pretes dianalisis secara deskriptif.Hasil deskripsi statistik data pretes menunjukkan bahwa rata-rata skor pretes kelas eksperimen 1yaitu 42,09dan rata-rata skor pretes kelas eksperimen 2 yaitu 42,57. Hal ini menujukan bahwa rata-rata skor pretes antara kelas eksperimen 1 dan kelas eksperimen 2 tidak berbeda secara signifikan.

Setelah kedua kelas diberi perlakuan maka pada akhir pertemuan diberikan postes.Berikut hasil 
perhitungan statistik deskriptif eksperimen 2. posteskelas eksperimen 1 dan kelas

Tabel 1. Deskripsi Statistik Skor Postes

\begin{tabular}{|l|c|c|c|c|c|c|}
\hline Kelas & N & Min. & Maks. & $\begin{array}{c}\text { Std. } \\
\text { Deviasi }\end{array}$ & Mean & Kriteria \\
\hline Eksperimen 1 & 33 & 0,28 & 0,91 & 0,1408 & 0,615 & Sedang \\
\hline Eksperimen 2 & 35 & 0,13 & 0,83 & 0,1708 & 0,509 & Sedang \\
\hline
\end{tabular}

$$
\text { Berdasarkan tabel } 1 \text { dapat }
$$

diketahui bahwa terdapat perbedaan rata-rata skor postes antara kelas eksperimen 1 dan kelas eksperimen 2.
Selanjutnya hasil perhitungan statistik deskriptif N-gain kelas eksperimen 1 dan kelas eksperimen 2 sebagai berikut.

Tabel 2. Deskripsi Statistik Data N-gain

\begin{tabular}{|c|c|c|c|c|c|c|}
\hline Kelas & N & Mean & SMI & $\begin{array}{c}\text { Std. } \\
\text { Deviasi }\end{array}$ & Min. & Maks. \\
\hline Eksperimen 1 & 33 & 77,03 & 100 & 10,501 & 46 & 96 \\
\hline Eksperimen 2 & 35 & 71,74 & 100 & 10,681 & 46 & 92 \\
\hline
\end{tabular}

Berdasarkan Tabel 2 dapat diketahui bahwa rata-rata indeks gain kelas eksperimen 1 lebih tinggi daripada nilai rata-rata $\mathrm{N}$-gain kelas eksperimen 2. Sehingga terdapat perbedaan rata-rata $\mathrm{N}$-gain antara kelas eksperimen 1 dan kelas eksperimen 2.

Sebelum dilakukan pengujian hipotesis, terlebih dahulu dilakukan analisis data uji normalitas dan uji homogenitas.Uji normalitas dilakukan dengan menggunakan uji KolmorogovSmirnov. Hipotesis pengujian normalitas adalah sebagai berikut.

$H_{0}$ : Sampel yang berasal dari populasi berdistribusi normal

$H_{1}$ : Sampel yang berasal dari populasi tidak berdistribusi normal
Levene's test dengan taraf signifikansi $5 \%$. Hipotesis pengujian homogenitas adalah sebagai berikut.

$H_{0}: \sigma_{1}{ }^{2}=\sigma_{2}{ }^{2}$, varians data kedua kelas homogen

$H_{1}:{\sigma_{1}}^{2} \neq{\sigma_{2}}^{2}$, varians data kedua kelas tidak homogen

Kriteria pengujian hipotesis berdasarkan nilai probabilitas sebagai berikut (Siregar, 2015:159).

Jika probabilitas (sig.) $\geq \alpha$ dengan $\alpha=0,05$ maka $H_{0}$ diterima

Jika probabilitas (sig.) $<\alpha$ dengan $\alpha=0,05$ maka $H_{0}$ ditolak

Hasil pengujian normalitas dan homogenitas untuk pretes, postes dan $\mathrm{N}$-gain disajikan pada Tabel 3 .

Tabel 3. Hasil normalitas dan Homogenitas Pretes, postes dan N-gain 


\begin{tabular}{|c|c|c|c|c|c|c|}
\hline Kelas & \multicolumn{3}{|c|}{ Normalitas } & \multicolumn{3}{c|}{ Homogenitas } \\
\hline & Pretes & Postes & N-gain & Pretes & Postes & N-gain \\
\hline Eksperimen 1 & 0,200 & 0,055 & 0,150 & \multirow{2}{*}{0,583} & \multirow{2}{*}{0,833} & \multirow{2}{*}{0,189} \\
\hline Eksperimen 2 & 0,114 & 0,147 & 0,200 & & \multicolumn{2}{|c|}{} \\
\hline
\end{tabular}

Dari Tabel 3, signifikansi normalitas data pretes, postes dan $\mathrm{N}$ gain $>0,05$ maka $H_{0}$ diterima artinya data berdistribusi normal.Sig homogenitaspretes, postes, dan $\mathrm{N}$-gain $>0,05$ maka $\mathrm{Ho}$ diterima artinya varians data kedua kelas homogen. Karena data normal dan homogen dilakukan uji perbedaandua rata-rata untuk pretes, postes, dan $\mathrm{N}$-gain menggunakan uji IndependentSample T-Test.

Rumusan hipotesis uji perbedaan dua rata-rata data pretes antara kelas eksperimen 1 dan kelas eksperimen 2 sebagai berikut.

$H_{0}: \mu_{1}=\mu_{2}$, tidak terdapat perbedaan rata-rata skor pretes kemampuan berpikir kreatif matematis yang signifikan antara siswa yang mendapatkanmodel pembelajaran mind mapping berbasis pengoptimalan fungsi otak kanan dan model Problem Based Learning

$H_{1}: \mu_{1} \neq \mu_{2}$, terdapat perbedaan ratarata skor pretes kemampuan berpikir kreatif matematis yang signifikan antara siswa yang mendapatkanmodel pembelajaran mind mapping berbasis pengoptimalan fungsi otak kanan dan model Problem Based Learning

Rumusan hipotesis uji perbedaan dua rata-rata data postes antara kelas eksperimen 1 dan kelas eksperimen 2 adalah sebagai berikut.

$H_{0}: \mu_{1}=\mu_{2}$, tidak terdapat perbedaan rata-rata skor postes kemampuan berpikir kreatif matematis antara siswa yang mendapatkanmodel pembelajaran mind mapping berbasis pengoptimalan fungsi otak kanan dan model Problem Based Learning

$H_{1}: \mu_{1} \neq \mu_{2}$, terdapat perbedaan ratarata skor postes kemampuan berpikir kreatif matematis antara siswa yang mendapatkanmodel pembelajaran mind mapping berbasis pengoptimalan fungsi otak kanan dan model Problem Based Learning

Rumusan hipotesis uji perbedaan dua rata-rata data $\mathrm{N}$-gain antara kelas eksperimen 1 dan kelas eksperimen 2 sebagai berikut.

$H_{0}: \mu_{1}=\mu_{2}$, tidak terdapat perbedaan rata-rata $\mathrm{N}$-gain kemampuan berpikir kreatif matematis antara siswa yang mendapatkanmodel pembelajaran mind mapping berbasis pengoptimalan fungsi otak kanan dan model Problem Based Learning

$H_{1}: \mu_{1} \neq \mu_{2}$, terdapat perbedaan ratarata $\mathrm{N}$-gain kemampuan berpikir kreatif matematis antara siswa yang mendapatkanmodel pembelajaran mind mapping berbasis pengoptimalan fungsi otak kanan 
dan model Problem Based Learning

Kriteria pengujian hipotesis uji perbedaan dua rata-rata pretes, postes dan $\mathrm{N}$-gain berdasarkan nilai probabilitas sebagai berikut (Siregar, 2015:188).

Jika probabilitas (sig.) $<\alpha$ dengan $\alpha=0,05$ maka $H_{0}$ ditolak
Jika probabilitas (sig.) $\geq \alpha$ dengan $\alpha=0,05$ maka $H_{0}$ diterima

Hasil pengujian perbedaan dua rata-rata untuk pretes, postes dan $\mathrm{N}$-gain disajikan pada Tabel 4.

Tabel 4. Hasil Perbedaan Dua Rata-rata Data Pretes, Postes dan N-gain

\begin{tabular}{|c|c|c|}
\hline Pretes & Postes & N-Gain \\
\hline 0,823 & 0,044 & 0,007 \\
\hline
\end{tabular}

Berdasarkan tabel 4 dapat dilihat sig. pretes yaitu $0.832>0,05$ maka $H_{0}$ diterima.Dapat disimpulkan bahwa tidak terdapat perbedaan rata-rata skor pretes kemampuan berpikir kreatif matematis yang signifikan antara kelas eksperimen 1 dan kelas eksperimen 2.Dari hasil perbedaan dua rata-rata postes menunjukkan bahwa sig $=$ $0,044<0,05$ maka $H_{0}$ ditolak. Dapat disimpulkan bahwa terdapat perbedaan rata-rata kemampuan berpikir kreatif matematis antara siswa yang mendapatkanmodel pembelajaran mind mapping berbasis pengoptimalan fungsi otak kanan dan model Problem Based Learning.Dari hasil uji perbedaan dua rata-rata $\mathrm{N}$-gain menunjukkan bahwa sig $=0,007<0,05$ maka $H_{0}$ ditolak. Dapat disimpulkan bahwa terdapat perbedaan rata-rata $\mathrm{N}$-gain kemampuan berpikir kreatif matematis antara siswa yang mendapatkanmodel pembelajaran mind mapping berbasis pengoptimalan fungsi otak kanan dan model Problem Based Learning.

Berdasarkan hasil angket, presentase rata-rata jawaban siswa kelas eksperimen 1 sebesar 47\%.Artinya, hampir setengahnya siswa kelas eksperimen 1 telah memiliki minat terhadap matematika dan pembelajaran model mind mapping berbasis pengoptimalan fungsi otak kanan.Sedangkan pada kelas eksperimen 2, presentase rata-rata jawaban siswa sebesar 46\%.Artinya, hampir setengahnya siswa kelas eksperimen 2 telah memiliki minat terhadap matematika dan pembelajaran model Problem Based Learning.

\section{Pembahasan}

\section{Kemampuan Berpikir Kreatif Matematis}

Hasil pengujian hipotesis data pretes kemampuan berpikir kreatif matematis siswa kedua kelas memiliki kemampuan awal yang sama atau tidak berbeda secara signifikan. Hal ini menunjukkan bahwa kemampuan berpikir kreatif matematis siswa masih belum maksimal, siswa masih terpaku pada satu cara padahal banyak alternatif jawaban lain. Karena kedua kelas memiliki kemampuan awal yang sama, maka dilakukan proses penelitian dengan memulai proses pembelajaran. 
Kelas eksperimen 1 mendapatkan modelmind mapping berbasis pengoptimalan fungsi otak kanan sedangkan kelas eksperimen 2 mendapatkan model Problem Based Learning, kedua kelas diberikan materi yang sama yaitu Segiempat.

Setelah melalui proses pembelajaran, pada akhir pertemuan diberikan postes. Hasil pengujian hipotesis data postes menunjukkan bahwa terdapat perbedaan kemampuan berpikir kreatif matematis antara siswa yang mendapatkan model mind mapping berbasis pengoptimalan fungsi otak kanan dan model Problem Based Learning.Hal ini sejalan dengan hasil penelitian sebelumnya yang dilakukan oleh Manurung (2016) yang menyebutkan bahwaterdapat perbedaan yang signifikan hasil belajar siswa yang diberi pengajaran dengan menerapkan model pembelajaran mind mapping dengan siswa yang diberikan pengajaran dengan model pembelajaran problem based learning.

Problem based learning mampu memfasilitasi kemampuan berpikir kreatif matematis siswa dengan baik. Karena melalui problem-based learning, siswa menjadi lebih berani untuk menyampaikan penjelasan, pendapat atau jawaban dari suatu masalah (Purwaingrum, 2016).

Hasil analisis data ketercapaian kemampuan berpikir kreatif per aspek menunjukkan bahwa kemampuan berpikir kreatif aspek kelancaran dan aspek elaborasi kelas eksperimen 1 lebih tinggi daripada kelas eksperimen2. Presentase postes kemampuan berpikir kreatif matematis pada aspek kelancaran (fluency) 89\% dengan kriteria kreatif, keluwesan (flexibility) $56 \%$ dengan kriteria kurang kreatif dan elaborasi (elaboration) $86 \%$ dengan kriteria kreatif. Sedangkan untuk kelas eksperimen 2 kemampuan berpikir kreatif aspek kelancaran (fluency) 77\% dengan kriteria kurang kreatif, keluwesan (flexibility) $57 \%$ dengan kriteria kurang kreatif dan elaborasi (elaboration) $80 \%$ dengan kriteria kreatif.

\section{Peningkatan Kemampuan Berpikir Kreatif Matematis Siswa}

Berdasarkan hasil skor rata-rata $\mathrm{N}$-gain kelas eksperimen 1 dan kelas eksperimen 2 dapat disimpulkan bahwa terdapat perbedaan peningkatan kemampuan berpikir kreatif matematis siswa antara kedua kelas, yaitu pada kelas eksperimen 1 meningkat sebesar 61\% dan kelas eksperimen 2 sebesar $50 \%$. Hasil skor rata-rata peningkatan kemampuan berpikir kreatif matematis siswa kelas eksperimen 1 lebih tinggi daripada kelas eksperimen 2Hasil pengujian hipotesis data N-gain menunjukkan bahwa terdapat perbedaan peningkatan kemampuan berpikir kreatif matematis antara siswa yang mendapatkan model mind mapping berbasis pengoptimalan fungsi otak kanan dan model Problem Based Learning. Hal ini sejalan dengan penelitian sebelumnyayang dilakukan oleh Dasrusman (2014) menunjukkan bahwa metode mind mapping memudahkan siswa dalam proses mengkonstruksi kemampuan awal dalam pembuatan mind map dan berpengaruh besar dalam peningkatan kemampuan berpikir kreatif matematis.Selanjutnya, hasil penelitian 
Khoiri dkk.(2013) menunjukkan bahwa kemampuan berpikir kreatif siswa pada kelas yang menggunakan pembelajaran model Problem Based Learning berbantuan multimedia meningkat.

\section{Respon Siswa terhadap Pembelajaran}

Secara umum siswa kelas eksperimen 1 dan kelas eksperimen 2 telah memiliki minat terhadap matematika dan pembelajarannya. Hal ini dapat dilihat dari respon siswa terhadap matematika dengan presentase rata-rata $46 \%$ untuk kelas eksperimen 1 dan presentase rata-rata $48 \%$ pada kelas eksperimen 2. Untuk respon siswa terhadap penerapan model mind mapping berbasis pengoptimalan fungsi otak kanan sebesar $48 \%$ yang artinya hampir setengahnya siswa kelas eksperimen 1 telah memiliki minat terhadap pembelajaran yang dilaksanakan. Untuk respon siswa terhadap penerapan model Problem Based Learning sebesar $44 \%$ yang artinya hampir setengahnya siswa kelas eksperimen 2 telah memiliki minat terhadap pembelajaran yang dilaksanakan.

Secara keseluruhan presentase rata-rata respon siswa kelas eksperimen 1 adalah 47\%, artinya hampir setengahnya siswa menunjukkan minat terhadap pelajaran matematika dan penggunaan model mind mapping berbasis pengoptimalan fungsi otak kanan. Sedangkan presentase rata-rata respon siswa kelas eksperimen 2 adalah $46 \%$, artinya hampir setengahnya siswa menunjukkan minat terhadap pelajaran matematika dan penggunaan model Problem Based Learning. Respon dari siswa tidak mencapai 50\% karena dalam pembelajaran tidak semua siswa menyukai matematika.Respon minat siswa didapat karena siswa terlibat langsung dalam pembelajaran.

\section{SIMPULAN DAN SARAN}

\section{Simpulan}

Berdasarkan hasil penelitian dan pembahasan disimpulkan bahwa:

1. terdapat perbedaan kemampuan berpikir kreatif matematis antara siswa yang mendapatkan model mind mapping berbasis pengoptimalan fungsi otak kanan dan siswa yang mendapatkan model Problem Based Learning.

2. terdapat perbedaan peningkatan kemampuan berpikir kreatif matematis antara siswa yang mendapatkan model mind mapping berbasis pengoptimalan fungsi otak kanan dan siswa yang mendapatkan model Problem Based Learning.

3. Presentase rata-rata respon siswa menunjukkan bahwa hampir setengahnya siswa menunjukkan minat terhadap model mind mapping berbasis pengoptimalan fungsi otak kanan dan model Problem Based Learning.

\section{Saran}

Berdasarkan kesimpulan yang diperoleh maka dapat dikemukakan saran-saran sebagai berikut.

1. Siswa hendaknya lebih berperan aktif dalam proses belajar, kreatif dalam setiap kegiatan belajar mengajar dan selalu menumbuhkan 
motivasi belajar matematika sehingga memperoleh hasil belajar yang optimal.

2. Model mind mapping berbasis pengoptimalan fungsi otak kanan dan model Problem Based Learning dapat dijadikan sebagai alternatif model pembelajaran untuk meningkatkan kemampuan berpikir kreatif matematis.

3. Pihak sekolah dapat melakukan kerjasama untuk mencari solusi dalam mengatasi berbagai permasalahan khususnya dalam pembelajaran dengan mendukung penerapan model pembelajaran yang menarik di sekolah.

4. Peningkatan kemampuan berpikir kreatif matematis siswa masih dalam kategori sedang, maka diperlukan adanya penelitian lebih lanjut sehingga peningkatan kemampuan berpikir kreatif matematis dapat lebih optimal.

\section{DAFTAR PUSTAKA}

Darusman,R. (2014). Penerapan Metode Mind Mapping (Peta Pikiran) untuk Meningkatkan Kemampuan Berpikir kreatif Matematik Siswa SMP.Jurnal Ilmiah Program Studi Matematika STKIP Siliwangi Bandung, Vol 3(2) pp. 164-172.

Erasanti, P.D. (2016). Perbandingan Peningkatan Kemampuan Berpikir Kritis Matematis dan Self-Concept Siswa SMP Antara yang Belajar dengan Pendekatan Metacognitive Guidance dan Saintifik.Skripsi FPMIPA UPI Bandung.

Fardah, D.K. (2012). Analisis Proses dan Kemampuan Berpikir Kreatif
Siswa dalam Matematika Melalui Tugas Open-Ended. Jurnal Kreano Jurusan Matematika FMIPA UNNES Vol. 3(2). pp. 19.

Jellen, H., G. \& Urban, K., K. (1989). Expanding Worldwide Awareness of Creative Potential. The Creative Child and Adult Quarterly. 5(11), 42-49.

Khoiri, W. dkk. (2013). Problem Based Learning Berbantuan Multimedia dalam Pembelajaran Matematika untuk Meningkatkan Kemampuan Berpikir Kreatif. Unnes Journal of Mathematics Education. Vol. 2 (1), pp. 114-121.

Krathwohl, D.R. (2002). A Revision of Bloom's Taxonomy: An Overview. Journal of Education Theory Into Practice. Vol. 41(4). Pp. 212-218

Lestari, K.E \& Yudhanegara, W. (2015). Penelitian Pendidikan Matematika. Bandung : Refika Aditama

Manurung, E. D. T. (2016). Perbandingan Penerapan Model Pembelajaran Mind Mapping dengan Model Problem Based Learning (PBL) dalam Hasil Belajar Siswa.Skripsi Universitas Medan.

Moma, L. (2015). Pengembangan Instrumen Kemampuan Berpikir Kreatif Matematis untuk Siswa SMP.Jurnal Matematika Delta Pi dan Pendidikan Matematika.Universitas Pattimura Ambon.

Purwaningrum, J., P. (2016). Pengaruh Problem-Based Learning "What's another Way dan Discoveri Learning Dalam Meningkatkan Kemampuan Berpikir Kreatif Matematis Siswa SMP. Jurnal Edukasi dan Sains Matematika UNIKU Vol. 2 (2) pp. 53-66. 
Sani, R.A. 2013. Inovasi Pembelajaran. Jakarta: Bumi Aksara.

Siregar, S. (2015). Metode Penelitian Kuantitatif: Dilengkapi Perbandingan Perhitungan Manual \& SPSS. Jakarta: Prenadamedia Grup

Trianto. (2017). Mendesain Model Pembelajaran Inovatif, Progresif dan kontekstual: Konsep, Landasan dan Impelmentasinya pada Kurikulum 2013. Jakarta: Prenadamedia Grup

Wahyudin. (2008). Pembelajaran dan Model-model Pembelajaran.

Bandung: 